\title{
The Presbyterians Divest
}

\author{
Ronald R. Stockton
}

Dr. Stockton is a professor of political science at the University of Michigan-Dearborn. He would like to thank Jane Stockton, Vernon Broyes, Allan Gale and Carol Hylkems for their careful reading of an earlier version.

I June 2014, the $221^{\text {st }}$ Presbyterian General Assembly, meeting in Detroit, decided by a vote of 310 to 303 to sell their holdings in three corporations entangled with the Israeli occupation of Palestinian territories. They had passed a similar resolution in 2004 but modified it the following year to permit corporate engagement. In 2012, a resolution to divest had failed by two votes. Now it passed by seven. ${ }^{1}$

Anyone thinking that this decision centered upon selling stocks is overlooking the broader issues at work. Nothing involving a challenge to Israel is easy, and it is almost never limited to the issues at hand. This article will discuss the history of the decision, the mechanism whereby it was made, the debate that surrounded it, and the peripheral but highly significant issues discussed.

This vote did not come out of nowhere. Three decades ago, in 1976, the Presbyterian Church decided to invest only in "socially responsible" stocks. Faced with the injustice of apartheid in South Africa, it set up its Mission Responsibility Through Investment Committee (MRTI) to monitor its portfolio. Today, two investment bodies, the Pension Fund and the
Foundation, manage a total of $\$ 9$ billion. Both have a "fiduciary" obligation to act on behalf of the denomination to maximize its returns. This is particularly difficult for a body committed to moral principles of justice if high returns come from what have historically been called "ill-gotten gains." Should they invest in casinos, film companies that make pornographic movies or banks that launder money? Obviously not, although the Vatican discovered in the 1980s that its investment bodies had been doing exactly that. The Presbyterians specifically indicated that they would not invest in companies involved in tobacco, alcohol, gambling, human-rights abuses, weapons production or any non-peaceful activity. Pursuant to this policy, they sold their shares in several companies that supported apartheid. Over the decades, they have refused to hold shares in companies that make war matériel (such as Raytheon or Lockheed). The logic of this strategy is not that they are changing the way the world operates. Nike will still pay substandard wages overseas even if the Presbyterians shun their company. The issue is twofold: 1) They want to "witness" to the world that they do not approve of certain activities, and 2) They do not want to profit 
from corporate practices that they do not consider appropriate.

In 2004, the General Assembly, the biennial governance meeting, voted overwhelmingly (431-62) to begin a "phased, selective" divestment from companies that profited from or were entangled in the Israeli occupation of Palestinian lands. Four were chosen - Caterpillar, Motorola, ITT Industries and United Technologies with Citigroup added for allegedly moving money to Islamic extremist groups.

When the General Assembly adopted that position, two things happened. First, their investment bodies resisted, saying that their fiduciary

obligations overrode the recommendations of the General Assembly. Second, supporters of Israel (Jews but also Presbyterians) unleashed a shocking barrage of venom against the denomination and those who supported the resolutions. The supporters were said to be anti-Semites, racists and advocates of mass murder who allegedly wanted to see the destruction of Israel and its economy, and a host of other sins. Some high-profile critics misrepresented or even fabricated what was in the overtures. The two U.S. national political parties went so far as to call for prosecution of those who advocated illegal boycotts of Israel. The brouhaha (a restrained term) from that decision was so great that the 2006 General Assembly modified its original decision and voted to continue a process of corporate engagement with the targeted companies and to pursue "positive investment."

By the time the General Assembly met in 2014 , the context was not good. Amer- ican-led peace talks between the Israelis and Palestinians had collapsed, with U.S. negotiators pointing to Prime Minister Netanyahu as the primary cause of the breakdown. The Gaza War (with 72 dead Israelis and over 2,100 dead Palestinians) was about to begin but did not fully explode until after the Detroit meetings ended. Regarding Presbyterians and Jews, relations had reached a serious low. In 2012, a new divestment resolution failed by two votes (333-331). Earlier that year, Presbyterians were prominent when 15 Christian, mostly Protestant, leaders had sent a letter to Congress asking it to investigate Israeli human-rights abuses and consider cutting off aid. Outraged Jewish groups terminated all dialogue with them. ${ }^{3}$ Contacts were not resumed until April 2014, two months before the General Assembly met.

Within Presbyterian congregations there was a sense that the church should be doing what it could to address the problems. The Presbyterian Panel, composed of approximately 2,000 church members, elders (congregational lay leaders) and pastors, had asked Middle East-related questions in its 2009 member survey. ${ }^{4}$ On Israel-Palestine issues, it showed that the dominant thinking was unsympathetic to Israeli policy. Asked about the "expansion of Jewish settlements further into the West Bank and East Jerusalem on Palestinian land," support was minimal: 10 percent of members, 10 percent of elders, 6 percent of clergy. On whether the church should be trying to improve the situation, 55 percent of members, 59 percent of elders and 74 
percent of pastors thought it should. Regarding whether the church "should avoid making investment profits from unjust situations," 68 percent of members, 71 percent of elders and 70 percent of pastors said yes. Asked about a hypothetical situation in which efforts to persuade corporations to change their harmful policies had failed, 66 percent of members, 66 percent of elders, and 64 percent of pastors felt it should shift its investments. But issues involving the Middle East did not exist in a separate universe. Asked about the importance of "maintaining positive relations with members of the U.S. Jewish community," 40 percent of members, 37 percent of elders and 32 percent of clergy saw this as a priority. Thus, while there clearly were doubts about Israeli policies and sympathy for an active church policy, there was an implicit caveat that Presbyterian activism not harm relations with the Jewish community. This caveat produced much of the tension in the General Assembly.

Ironically, Jewish opinion was even more complex. A Pew Research study of American Jews in 2013 found serious differences of opinion within the Jewish community regarding Israel and its policies. ${ }^{5}$ While 69 percent were very or somewhat attached to the state, 44 percent thought that Jewish settlements were hurting Israeli security (17 percent thought they were helping) and only 38 percent thought the Israeli government was making a sincere effort to bring about a peace settlement. As on other issues, there were divisions within the community. Jewish Republicans had confidence in the Israeli government (62 percent), while Democrats did not (32 percent). Likewise, Orthodox Jews supported the government (61 percent) more than did Reform Jews (36 percent). Doubts about Israel did not pit Presbyterians against Jews as much as it did Republican and Orthodox Jews against Democratic and Reform Jews.

In 2014, there were nine resolutions ("overtures" in Presbyterian terminology) before the General Assembly relevant to the Israel-Palestinian conflict. Six supported divestment in one form or another. One took an opposite tack and called for peacemaking, two states, travel to the Holy Land and interfaith dialogue. Of the two that did not focus on divestment, neither would make Mr. Netanyahu happy. One called for equal rights for Israelis and Palestinians, including freedom from deportation and detention without charge, and an end to the wall and bypass roads (which allow Jewish settlers living in the occupied West Bank to drive directly to their settlements without passing through Palestinian towns). The other overture called for a reassessment of the denomination's longstanding call for a two-state solution to the conflict. The resolution said that the two-state strategy had obviously been undermined by the settlement process, so it was unrealistic to remain committed to it, and that every time it is reaffirmed, it just gives the Israelis further opportunity to expand their occupation of Palestinian land. It condemned the matrix of occupation for having made a Palestinian state impossible, indicating that there should be an alternative position. The resolutions called for a study to assess the merit of continuing that position. There was also a tenth resolution on the use of the term "Israel" in the Presbyterian hymnal and other literature. This will be discussed separately.

The General Assembly voted 310 to 303 to proceed with the sales of shares in three companies: Caterpillar, Motorola Solutions and Hewlett-Packard. According to the MRTI report, these particular 
Middle East Policy, Vol. XXII, No. 1, Spring 2015

companies were chosen for the following reasons: ${ }^{6}$

- Caterpillar sells heavy equipment used by the Israeli military and by contractors to destroy Palestinian homes and farmland and to construct segregated roads and the separation barrier.

- Hewlett-Packard profits from biometric scanners used at checkpoints. It also sells hardware to the Israeli navy and manages its information technology, including that related to the ongoing naval blockade of Gaza.

- Motorola Solutions provides an integrated communications system to the Israeli government for military use. It also provides ruggedized cell phones to the Israel Defense Forces (IDF) for use in the Occupied Territories and wide-area surveillance systems for use in Israeli settlements.

MRTI described how its efforts to engage these companies through proxy voting, dialogue with companies, shareholder resolutions and public appeals had failed. In some cases, corporate executives would not even meet with them. "We have regretfully concluded that further dialogue... will not be fruitful and we are therefore regretfully recommending divestment from these three companies. We have attempted... to be faithful to the assignment that the General Assembly gave the committee in 2004 and has updated at every successive Assembly."

The Presbyterians had \$21 million invested in the three companies. Caterpillar alone had a market capitalization of $\$ 60.9$ billion. In a typical day of trading (October 6, 2014), 643,000 shares changed hands. This action would have no impact on the companies themselves or upon Israel's ability to function. It was purely symbolic and ethical, which made it even more controversial.

\section{THE BDS MOVEMENT}

The $221^{\text {st }}$ General Assembly met within the context of a surging international boycott, divestment and sanctions (BDS) movement. BDS links together 170 Palestinian parties, organizations, trade unions and movements. They represent Palestinian refugees, Palestinians in the Occupied Territories and Palestinian citizens of Israel. Their mission statement defines three goals: ${ }^{7}$ first, ending the occupation and colonization of all Arab lands occupied in June 1967 and dismantling the wall; second, recognizing the fundamental rights of the Arab-Palestinian citizens of Israel to full equality; and, third, respecting, protecting and promoting the rights of Palestinian refugees to return to their homes and properties as stipulated in UN Resolution 194 (which specifies two options, return of their properties or compensation).

BDS does not urge a blanket boycott of Israel. It targets products and companies that profit from the violation of Palestinian rights as well as Israeli sporting, cultural and academic institutions that defend or "whitewash" the oppression of Palestinians. It also asks that university investment portfolios and pension funds not be used to finance such companies. Its goal is to raise awareness, educate society and encourage companies to use their economic influence to pressure Israel to end its systematic denial of Palestinian rights.

BDS has won support in the United States and around the world from religious groups, student groups, unions and other associations. Bishop Desmond Tutu of South Africa has endorsed it. In the United States, the BDS movement is com- 
mon on university campuses, frequently embraced by the student government but repudiated by the administration. Several denominations have divested or modified their investment policies, often using the phrase "positive investment." They include the World Council of Churches, the United Church of Christ, the Episcopal Church, the Evangelical Lutheran Church in America, the Church of England, the United Church of Canada, the Mennonite Central Committee and the Quakers. Days before the Presbyterians met, the Methodists sold their shares in G4S because of its involvement with the Israeli prison system and the military occupation of the Palestinian territories. ${ }^{8}$

In spite of what critics said, BDS was not on the Presbyterian agenda. There was no call to boycott Israel. No one proposed divesting from all companies that operate in Israel or called for sanctions against Israel by any government entity. In terms of the overtures before the General Assembly, BDS was a straw man.

\section{"ZIONISM UNSETTLED"}

In 2011, the Israel/Palestine Mission Network (IPMN), an affiliate of the denomination, established a working group to explore the history, doctrines and forms of Zionism. (Political Zionism as understood by Theodore Herzl, the founder of the movement, is the belief that Jews are not just a religious or ethnic group but a national people living in temporary exile and awaiting a return to their homeland. ${ }^{9}$ ) The Friends of Sabeel North America, a Palestinian support group not affiliated with the denomination, invited IPMN to collaborate in developing a collection of essays on Jewish Zionism and Christian Zionism (discussed below). The book that emerged was called Zionism and the Quest for
Justice in the Holy Land. ${ }^{10}$ In 2014, IPMN produced Zionism Unsettled: A Congregational Study Guide, a 72-page study manual with an accompanying DVD. ${ }^{11}$ Its introductory statement suggested that it might be used in conjunction with the essays in Zionism and the Quest for Justice.

Zionism Unsettled made several key points explained in this paragraph. It criticized the "so-called peace process" as a "cover" for "irreversible territorial and demographic facts on the ground." It said this was creating a "one-state solution" that was "ultimately unsustainable." While Zionism was originally an "ideological movement established to remedy Jewish victimization," it had changed so that now Palestinians are struggling to be recognized as its victims. Many Jews over the past century have been concerned about this contradiction, which grows from theological “exceptionalism” (p. 5-6).

Christian exceptionalist beliefs and
actions contributed to the Nazi Holo-
caust, the genocide of Native Ameri-
cans, and countless other instances
of tragic brutality. Exceptionalist
doctrines and behaviors within Islam
have contributed to grievous human
rights abuses such as the massacres
during the closing days of the Otto-
man Empire which crescendoed with
the Armenian genocide of 1915 .

Now Jews are discovering the dangers of "theocratic fanaticism harnessed by state power" (pp. 8-9). The authors call this "Constantinian Religion," an allusion to the period in history when Christianity and power embraced each other. The text quoted many Israeli leaders (most from the Revisionist tradition) who illustrate this mindset, Menachem Begin and Benjamin Netanyahu among them. It also quoted 

dissented. It used phrases such as institutional racism, colonial movements, self-inflicted blindness and the spreading of fear (p. 23). It mentioned three traditions within Judaism: the tribal-nationalist-separatist tradition, the Torah-oriented tradition of the Pharisees, and the prophetic tradition that rejected the idea of a tribal god in favor of a god who would redeem all of humanity (p. 33). Islam is presented as "inclusive," as opposed to a Zionism captured by an ideology that is racist and focused upon ethnic cleans- many Jews (Israeli and otherwise) who

a renunciation of the morally hazardous claims of a hierarchy of victimhood" ( $p$. 9). The document also included a critique of Christian Zionism.

\section{CHRISTIAN ZIONISM}

Christian Zionism is rooted in the belief that the emergence of a Jewish state in Palestine in 1948 was the fulfillment of Biblical prophecy. There is a corollary assumption that this event was somehow

As with attitudes towards Israel and its
policies, the division is not Evangelicals
and Jews against mainline Protestants, but
Evangelicals and Orthodox Jews against
mainline Protestants and Reform Jews.

linked to God's plan for the fulfillment of human destiny. ${ }^{13}$ The doctrine puts the state of Israel, and ing (pp. 50-51). One Palestinian Christian described Zionism as "a false theology"; by producing humiliation and deprivation it can "distort the image of God in us" and distort it in our oppressors. By turning religion into human ideology, it "strips the Word of God of its holiness, its universality and truth." According to one author, this is "the equivalent of declaring Zionism heretical,... a doctrine that promotes death rather than life" (pp. 56-57).

The reference to heresy (a false teaching) was informed by the South African experience, where Christian theologians declared apartheid to be a heresy because it created a false security, separated humans, generated hostilities between peoples, and promoted a false faith that offered happiness and peace for one community. ${ }^{12}$ Earlier, the authors had drawn another analogy. They said there must be "an expanded, inclusive understanding of the Nazi genocide in contemporary life, so that 'Never again!' applies not only to Jews but to all peoples, including Palestinians, and support for it, at the very center of Christian thinking. In various public-opinion studies, substantial minorities of Americans are shown to be sympathetic to these views.

A public-opinion poll in 2013 by Pew Research asked whether respondents believed that the land was given to the Jewish people by God. Forty percent of Jews did, compared to 55 percent of Christians. But there were big intragroup differences in both communities. Among Jews, 84 percent of Orthodox agreed but only 35 percent of Reform did. Among white Christians, 82 percent of Evangelicals agreed but only 47 percent of mainline Protestants. ${ }^{14}$ Thus, as with attitudes towards Israel and its policies, the division is not Evangelicals and Jews against mainline Protestants, but Evangelicals and Orthodox Jews against mainline Protestants and Reform Jews. Another study, in 2003, asked whether respondents thought the creation of Israel in 1948 was the fulfillment of prophecy. Thirty-six percent of Americans 
agreed. Responses correlated highly with whether one sympathized more with Israel or the Palestinians. Those who saw Israel as the fulfillment of prophecy supported it over the Palestinians by 57 percent to 9 percent. Those who disagreed supported it by 34 percent to 18 percent. $^{15}$

Three points are clear from the data. First, while there are definite divisions between Evangelicals and mainline Protestants, there are those within the mainline tradition who think as Christian Zionists think. A Presbyterian challenge to Christian Zionism will generate an internal reaction. Second, one's theology is correlated with one's views on the conflict. Theology does not stop at the church door. Third, for supporters of Israel, these debates were not just an intra-Presbyterian dispute over biblical interpretation. Christian Zionism is a major asset in the battle for public opinion.

The roots of Christian Zionism lie in a certain interpretation of Biblical texts. Christian Zionists often cite two verses, Genesis 12:2-3 ("I will bless them that bless thee, and curse them that curse thee") and Genesis 15:18-19, which describes how God made a promise to Abraham ("I give this land to you and your descendants from the wadi of Egypt to the Great River, the River Euphrates"). These are the famous "Nile to Euphrates" boundaries that would encompass parts of Jordan, Syria, Iraq and Egypt.

In 2004, the Presbyterians officially repudiated Christian Zionism. To them, it was not just a matter of politics but of "principles for interpreting scripture." Christian Zionism "weds religion with politics and interprets biblical faithfulness in terms of fidelity to Israel's future." 16 The overture referenced several previous statements over the decades (1944, 1978, 1983,
2001) to show this as a longstanding position. By way of how texts are misinterpreted, they specifically noted that "bless those who bless you" had historically called for justice for Jews, not support for the state of Israel. ${ }^{17}$

What has created tension is not just the different ways of interpreting texts, but that Christian Zionist views have become politicized. Right-wing televangelists such as Jerry Falwell, Pat Robertson and John Hagee have used these passages as a rationale to support the most militant elements in the Israeli political system. To Presbyterians, this is a false theology that is doing harm to Palestinians, in general, but also to Christian Palestinians, who are being blamed for views they do not accept. Its critics also think, although this is not their central concern, that it is doing harm to Jews and to Israel.

\section{OLD VS NEW ISRAEL}

A centuries-old issue is how to interpret the biblical passages that refer to "Israel" (as in Isaiah) and phrases such as the King of Israel or Jerusalem or references to the return of the Jews. Presbyterians view these as spiritual, historical or metaphysical terms, while Christian Zionists view them as referring to contemporary Israel.

An overture from the Presbytery of Chicago addressing these issues was often cited as a "third way." It was called "Perspectives on Presbyterian Church (USA) Support for a Just and Peaceful Compromise on the Israeli-Palestinian Conflict." The issue at hand was the new Presbyterian hymnal, ${ }^{18}$ which classifies songs according to theme (Advent, Christmas). One section, entitled "God's Covenant with Israel," contains 39 songs, several of which are inspired by Psalms. Three illustrate the tone: 
I, the Lord of Sea and Sky, I have heard my people cry. All who dwell in dark and sin, My hand will save.

(p. 69, "I the Lord of Sea and Sky")

How can we sing the Lord's song in a strange and bitter land

Can our voices veil the sorrow?

Lord God, hold your holy band.

(p. 72, "By the Babylon Rivers").

O God, restore our nation

Lord, irrigate dry souls,

That those who sow in sadness

May reap their Sheaves with gladness

And sing the song of joy

And sing the song of joy.

(p. 73, "When God Delivered Israel")

The overture said that the denomination should "distinguish between the biblical terms that refer to the ancient land of Israel and the modern political State of Israel." It suggested that the hymnal section entitled "God's Covenant with Israel" be changed to "God's Covenant with Ancient Israel" or even "God's Covenant with the Poor" or "Our Covenant with the Oppressed." It suggested inserting a sticker with the following message into the hymnals or other publications, making the following point:

Please note in using these texts that the biblical and liturgical "land of Israel" is not the same as the State of Israel established in 1948, which is a contemporary nation state. The Bible contains differing descriptions of the parameters of Israel. Promises of land generally come with obligations to God for justice to be practiced with all inhabitants. Later in Scripture, the Gospel is to be preached to "all nations"; in Jesus Christ all peoples are included in God's promise. Similarly, "Zion" is frequently used in the Bible as a reference to the city of Jerusalem, but in Christian tradition this does not refer primarily to a specific geographical location or political entity but to "the city of God" found throughout history and to the completion of God's purpose in the age to come. Presbyterian General Assemblies have affirmed the principle that the current physical Jerusalem be shared by Jews, Christians, and Muslims, both Palestinians and Israelis, living in peace with justice.

The overture failed to pass, possibly because a large number of commissioners received it late and did not have time to reflect upon it.

\section{WHAT IS AN OVERTURE?}

The Presbyterian Church (USA) is structured as a decentralized federation. It does not have bishops. Local congregations are aggregated into regional bodies called Presbyteries. Congregations send representatives to monthly or quarterly Presbytery meetings. Pastors are voting members, as are lay members allocated according to the size of the congregation. The denomination has a Book of Order that specifies procedures in a precise manner that other denominations might consider overregulated.

Many overtures are technical or administrative in nature. (One adopted in 2014 raised the amount that Presbyteries contribute per member to their national programs.) Some overtures address theological issues, such as whether to add the Belhar Confession to the list of official Presbyterian Confessions. Others address issues in the public arena. Scores in the past have addressed immigration, drug policy, women's rights and capital 
punishment. Others have focused upon international issues such as wars, conflicts or refugee problems; several countries have been named over the years, including Nigeria, Sudan, Columbia and China. The United States has been named several times for its various shortcomings. One hot-button issue before the General Assembly in 2014 was whether to redefine marriage as between "two persons" and whether to allow congregations the option of permitting same-sex marriage.

Regarding how positions are adopted, Presbyterians use the words "deliberation" and "discernment." Deliberation refers to extensive discussion. Discernment is more complex. It refers to a process whereby honest people, listening openly to one another, try to discover a path that God wants them to follow. In practice, an overture goes through several steps during which it is discussed, deliberated and, typically, transformed:

(1) Most overtures originate in a congregational governing body (the session) and are then adopted by a Presbytery, one of the 171 regional bodies that organize the nation's 10,000 Presbyterian congregations and 1.8 million members. When a Presbytery receives a proposed overture, it will deliberate, modify and vote on it. If it passes, it is forwarded to the national body for consideration at the next General Assembly. At this point, the overture is "owned" by the Presbytery and the congregation's name is removed.

(2) When it reaches the General Assembly, an overture is referred to the appropriate committee for processing - to the Committee on Middle East Issues for divestiture issues, for example. The committee will hold hearings to learn the perspectives of those with strong feelings about the overture. The committee can also consult with General Assembly staff or representatives of relevant or interested standing committees. These might include the Advisory Committee on Social Witness Policy, the Advocacy Committee for Racial Ethnic Concerns, or the Advocacy Committee on Women's Concerns. Most overtures get rewritten or consolidated before a vote.

(3) The overture is discussed by the whole body and voted upon. If it is a policy overture, the General Assembly vote is definitive. If it proposes modification of the Book of Order, it is sent to the Presbyteries for ratification.

(4) The denominational leadership often issues a public statement explaining how the overture will be interpreted and implemented.

I will describe this process and several key aspects of the particular decisions. Since I have followed this issue carefully for over a decade, I will offer my own observations on what happened and why. I attended the 2014 General Assembly two separate days. In those two days, I visited the various booths, attended the presentations on the resolutions, and went to the "moderator election" (the moderator is the top official in the church). One of the most impressive parts of the event was the exhibits. Scores of groups presented their perspectives and argued for their causes. Seeing that wealth of organizations makes one realize how diverse the Presbyterian Church is and why it is so difficult to keep tempers from flaring. Several groups dealt with Middle East issues, ranging from education to advocacy to selling Palestinian crafts. 
Middle East Policy, Vol. XXII, No. 1, Spring 2015

\section{THE PRESBYTERIAN DEBATE}

It would be an understatement to say that the Israel-related issues were controversial. In fact, they were seriously divisive. Sometimes the discourse became inflammatory. As someone who teaches hot-button classes ("The Israeli-Palestinian Conflict," "Religion and Politics"), I have developed some rules to help students navigate these

minefields.

One is, "Until

you can state

someone's

position to

their satisfac-

tion, and de-

fend it against

its critics, you

It is natural, if not healthy, that, when Presbyterians said they wanted to sell their shares in three stocks entangled in the Israeli occupation of Palestinian lands, some Jews would see ancient enemies arising once again. and misleading. why did they wait until now to issue that statement?" In fact, the statement, which was flashed on the Skype screen, had been adopted in 1990 and was labeled with that date. The allegation that this was a catchup statement was demonstrably inaccurate

There are various reasons why people say such things. Lay people might throw out slurs without thinking. Ideologues might use inflammatory language to bolster their arguments. Some of the debate had a polemical feel, as if partisans were just mobilizing arguments to support their case. Possibly some statements were rooted in simple bigotry. But perhaps there was something else at work, especially where Jews were concerned. There is a well-known pattern in conflict studies regarding how we perceive our enemies. When facing a threat, we reach back into our historical memory bank to conjure up images from battles past. Jews have terrifying memories of expulsion, mass murder, systematic discrimination, religious oppression and self-righteous contempt from religious leaders. It is natural, if not healthy, that, when Presbyterians said they wanted to sell their shares in three stocks entangled in the Israeli occupation of Palestinian lands, some Jews would see ancient enemies arising once again and think that the real goal was to destroy Israel, expel Jews from the Middle East, expose Jews to violence and generate theological and social anti-Semitism. ${ }^{19}$

As the meeting approached, various 
groups tried to define the issues so as to control the debate. The biggest guns in this engagement were two Open Letters, each bearing the signatures of an impressive collection of denominational leaders. The first of these Open Letters was initiated by Katharine Rhodes Henderson, president of Auburn Seminary, and two former moderators, Susan Andrews and John Buchanan. Commonly called the Buchanan letter, it had 27 sponsors. ${ }^{20}$ The second letter was signed by 76 individuals, eight of them former moderators. It was associated with former moderator Rick Ufford-Chase, then head of the Presbyterian Peace Fellowship. Both letters made reference to Zionism Unsettled. The Buchanan letter saw it as the ideological rationale for the various overtures before the body.

It starts by noting that the signers were "deeply disturbed by the escalating conflict" within the church over issues related to Israel/Palestine. They noted that the conflict was not new; what is new is the "focus and tone" of the debate. The church has always made clear that they opposed the occupation, but now "we are no longer debating how the occupation should end, but whether Israel should even exist." Zionism Unsettled makes the point with its statement that "the problem is Zionism" and that, if this is true, "then ending Zionism (i.e., Israel) is the solution." The signers felt it was "very telling" that the first affirmation of that publication came from David Duke, the notorious white supremacist and anti-Semite. ${ }^{21}$ That such a thing is available through the Presbyterian website, the signers considered "sickening." The spirit of this document, they assert, is reflected in the overtures before the General Assembly: one would reconsider the decades-long commitment to a two-state solution; creating a single state "in which Jews would no longer have a majority" would mean "an end to the state of Israel;" the spirit of Zionism Unsettled "is to bring an end to not just the 1967 occupation of Palestinian lands, but to having an independent state of Israel at all." They continue to argue that, by calling Israel an apartheid state rooted in a colonial movement, it "negates the legitimacy of Israel," denies it any share of the land, and denies "the ancient Jewish connection to and presence in the Holy Land." As for the overture to divest, the signers claim, it is being driven by the international BDS movement. As a whole, they conclude, the overtures before the Assembly are "misguided and damaging." 22

The Ufford-Chase Open Letter followed the Buchanan letter by one day. ${ }^{23}$ It quoted Martin Luther King's famous "Letter from a Birmingham Jail," in which he said white moderates were a greater stumbling block to black advancement than overt racists, being more devoted to order than to justice. King said, "Shallow understanding from people of good will is more frustrating than absolute misunderstanding from people of ill will." The Ufford-Chase signers suggested a four-pronged approach to the problem. First, view this as a matter of conscience: "It is a reasonable thing and a moral obligation - to assure that our financial investments reflect our core values as followers of Jesus." Second, see divestment as "a faithful, principled response to a call for nonviolent resistance from the Palestinian people....Simply put, they have asked us to stop funding their oppression." Third, remember that our witness matters: "No one cared what the Presbyterian Church (USA) believed about the evil of a decades-long occupation until we began to consider selling our stock.... This decision will lay the groundwork for 
peace with justice and genuine security for all who live within both Israel and Palestine." Finally, think of "Divestment Plus": This resolution will empower us to defend the rights of all peoples. "Let us work with colleagues in all religious traditions from around the world to reclaim our sacred texts from those who would steal them for purposes that are antithetical to our fundamental values of peace and harmony with one another."

Nobel Prize winner Archbishop Desmond Tutu of South Africa also weighed in with his own Open Letter to the General Assembly. ${ }^{24} \mathrm{He}$ urged them to "make a strong witness for reconciliation, justice and peace." He "especially" urged the denomination to name Israel as an apartheid state because of its occupation policies: "I know firsthand that Israel has created an apartheid reality within its borders and through its occupation. The parallels to my own beloved South Africa are painfully stark indeed." Tutu said there are only three alternatives for the future: one state, two states or "an apartheid state in perpetuity." To prevent disaster, he urged the denomination to divest from companies that contribute to that occupation. What we learned in South Africa is that "the only way to end apartheid peacefully was to force the powerful to the table through economic pressure." He concluded,

The overtures proposed at the General Assembly are not about delegitimizing the State of Israel, but about ending its suppression of 4,000,000 Palestinian sisters and brothers. It's about naming an unjust system and refusing to participate in it. The stubbornness of Israel's leaders in wanting to hold onto and settling land that is not theirs can only lead to tragedy for both peoples. For the sake of them both as
God's cherished, the strong witness of the two overtures is the only peaceful route left in the cause of justice and ultimate reconciliation.

An internet blogger called "Beloved Spear" (featuring an image of John Brown) made his own observations on the issues:

The question, for Presbyterians, is whether or not we can treat businesses who operate in Israel in the same way we treat businesses which operate in the United States. For example, the PC (USA) does not invest in American businesses that build or design weapons. We also do not, as a matter of principle, invest in the very profitable businesses that own or manage privatized prisons. We don't hold stock in Lockheed Martin. We don't hold stock in the Corrections Corporation of America. Do such businesses serve the security of the United States? Sure, on some level.... Would we be wealthier if we'd laid all our money into them? Just click those links, and see how profitable human brokenness can be. ${ }^{25}$

It goes without saying that there were hostile comments from the public, many in response to news items from the Presbyterian information office. While what follows is not a representative sample, the words show the intensity of feeling. Many comments accused the overture advocates of a refusal to recognize Israel's right to exist, asserted that God will bless those who stand with Israel, alleged an intent to murder all Israelis, asserted that Israel is in a fight for its very existence, alleged an intent to wipe Israel off the face of the earth, said that Presbyterians are turning their backs on the Jewish people, said that this was "a symbolic effort to humiliate our Jewish friends," and called it "a deep calumny to 
falsely equate Israel with apartheid South Africa." Comments often said that Israel is the most democratic and free nation in the Middle East. One said the overtures were the most outrageous action any Christian denomination has ever taken. There was a frequent and repeated use of words such as terrorist, criminal and one-sided.

Reverend Chris Leighton of the Institute for Christian and Jewish Studies developed in his own Open Letter a stinging critique of Zionism Unsettled. ${ }^{26}$ Leighton said the document was a "dishonest screed." He Perhaps the fact that the General Assembly had come within seven votes of divesting two years earlier made the outcome more likely and thus less do-ordie for the Jewish leadership. statements were particularly strong (especially those coming from organizations or leaders on the right of the Jewish spectrum), they were mild compared with those of 2004 and 2006. Perhaps the fact that other Christian denominations had divested during the past decade made this particular case less critical. Or perhaps it was the fact that most other denominations had divested through their governing councils while the Presbyterians deliberated through a mass assembly. Or perhaps the fact that the General Assembly had come within seven votes of divesting two years earlier was offended that it called Zionism a false theology, a heretical doctrine, and a pathology that inexorably leads to cultural genocide and ethnic cleansing. He said it contained "historical errors," especially in comparing Israel with apartheid-era South Africa; that Zionism Unsettled blamed Israel exclusively and exonerated the Palestinians by failing to mention suicide bombings or the Hamas Charter; that it failed to note the "culpability" of Syria and Iran in the conflict and the fact that the United States also has "blood on its hands"; that it portrays Islam as a religion of peace and "enlists various Jews to bolster their attacks"; that many of these Jews are marginal personalities; and that others have had their views distorted or mischaracterized. ${ }^{27}$

\section{JEWISH COMMENTS}

As one might expect, there were a great many Jewish comments on the overtures. These ranged from thoughtful, respectful and conciliatory to abusive. While some

made the outcome more likely and thus less do-or-die for the Jewish leadership.

Three American statements that were predictable in their intensity and intemperance illustrate the unpleasant side of the debate. One was from Ethan Felson, vice president of the Jewish Council for Public Affairs. Not only did he attribute unworthy motives to the supporters of divestment; his statement raised diversionary issues: "These backers of divestment want to return their church to a place of retrograde anti-Jewish theology, hostility to mainstream Jews and, of course, a blind eye to the responsibility of Hamas and Hezbollah on the Israel-Palestinian conflict and the steps Israelis are forced to take to defend themselves." ${ }^{28}$ Noam E. Marans, director of Interreligious and Intergroup Affairs for the American Jewish Committee, weighed in on Zionism Unsettled, calling it "virulently anti-Israel." As he described it, the authors "openly admit" that the issue is not about the territories but 
about "Israel's very existence." The guide engaged in "ignominious demonization and delegitimization of Israel" and did not "accept Israel's existence." ${ }^{29}$ A pro-Israeli group called Scholars for Peace in the Middle East saw a decades-long campaign "uniquely and solely aimed at Israel." Now there are 10 resolutions on this topic before the body, nine calling for "divestment in companies doing business with Israel, and one that questions whether Israel should exist at all...." These resolutions "feed into existential fears" and engage in "demonizing, dehumanizing or delegitimizing." Zionism Unsettled exhibits "similarity to the Protocols of the Elders of Zion." ${ }^{30}$

Overall, however, the Jewish reaction was more balanced and less inflammatory than in previous years. Four statements show the range of views and expressions.

\section{An Open Letter}

An internet-generated letter from 1,700 rabbis, cantors and Jewish religious students reached out with a very positive tone. The authors affirmed their "longstanding and deeply committed" engagement with Presbyterian-Jewish interreligious relations. At a time of "frayed nerves and sustained suspicions...our prayers are with the peacemakers." They praised Secretary of State John Kerry for his efforts and expressed their appreciation of the Presbyterian "commitment to peacemaking, human rights, and the particular Presbyterian concern for their fellow Christians whose spiritual aspirations include the establishment and sustenance of flourishing Christian communities in the Holy Land." They did, however, say they were "deeply concerned" that "oversimplifying a complex conflict and placing all the blame on one party, when both bear responsibility, increases conflict and division instead of promoting peace, reconciliation and mutual understanding." They said that the thing that "most reflects and magnifies our sadness" was Zionism Unsettled, which was "extraordinarily hurtful and incendiary." They looked toward a "new way forward" that would include both Jews and Presbyterians. ${ }^{31}$

\section{Rabbi Rick Jacobs}

The head of the 1.5-million-member Union for Reform Judaism, Rabbi Rick Jacobs, sent an open letter to the denomination and was invited to speak to the whole body. ${ }^{32}$ Rabbi Jacobs represented a progressive denomination within the Jewish community, one with a long history of commitment to social justice and interfaith relations. It opposes Israeli settlements and has worked with Presbyterians in various ways. The rabbi expressed several concerns in his letter. He said that "to have a friend, you must be a friend." With your partner's survival at stake, "It is a source of pain to us that you fail to show that same consistent sensitive and passionate concern for our Israeli civilian brothers, sisters and children...." Zionism, he said, is "the Jewish people's liberation movement." Divestment will not heal the problems in "this blood-soaked patch of land" but will "strengthen hardliners on both sides."

Turning to Zionism Unsettled, Rabbi Jacobs said that much of the rhetoric and materials produced by the Church are "profoundly troubling" and had left him "saddened, even horrified." He was very blunt: "There is no way to sugarcoat it: this document is a vicious attack on Judaism, the Jewish people and the state of Israel, negating the very theological legitimacy of the Jewish religion." It is "deeply troubling" to compare the situation in Israel with apartheid. It is as if "the 
Jewish yearning for our own homeland is somehow theologically and morally abhorrent, denying Jews their own identity as a people." He concluded by saying that Presbyterians and Jews were "at a crucial juncture in our relationship." It was a respectful letter, but not gentle.

\section{Rabbi Gary Bretton-Granatoor}

A more scholarly analysis by Rabbi Gary Bretton-Granatoor, vice president of the World Union for Progressive Judaism, deserves careful discussion. ${ }^{33}$ Rabbi Bretton-Granatoor wrote a longer piece that gave the impression of being rooted in serious research. It would have appealed to a thoughtful reader. The rabbi alleged that Presbyterian theology clings to an ancient set of hostile pre-Holocaust, anti-Semitic teachings about Jews. He wrote that while other Christian groups had dealt with the historical theological issues that separated Jews and Christians, the Presbyterians had not. Instead, they embrace "a warped theological framework that delegitimizes any Jewish attachment to the land of Israel."

The rabbi cited favorably the effort of Pope John XXIII to contemplate "how the Catholic Church might have contributed to an atmosphere that produced the Holocaust." The Pope "reevaluated the history of church-based anti-Judaism: the historical Christian belief that the Jewish covenant with God had been broken by perfidy, and that God had chosen a new covenantal partner, the church." The Vatican II document Nostra Aetate of 1965 formalized these teachings. The rabbi cited "four remarkable claims" in that document: "1) that Jews are not now - and never were - collectively responsible for the death of Jesus; 2) that God's covenant with the Jews is eternally valid; 3 ) that Jews should never be treated as if God had abandoned or cursed them; and 4) that anti-Semitism has no place whatsoever in Christianity." The rabbi noted, "Many Protestant denominations took up the same process of theological soul-searching by engaging "the issue of supersessionism and the validity of the Jewish covenant" (supersessionism or "replacement theology" meaning that the Christian covenant replaced and invalidated Judaism). The rabbi praised several denominations for their efforts - the Episcopalians, the Evangelical Lutherans and the United Methodists. But, he said, "The Presbyterians have not done this."

In fact, the Presbyterians went through a very similar set of deliberations. While their theology had never embraced antiSemitism or the "teaching of contempt" in the way that Catholic theology had done, ${ }^{34}$ they wanted to make it clear that they would have nothing to do with that form of thinking. In 1987, the General Assembly officially commended to the church a teaching document on the subject: "A Theological Understanding of the Relationship between Christians and Jews." ${ }^{35}$

The document begins with a discussion of several religious groups that had issued statements on Jewish-Christian relations. Leading their list was the Vatican's Nostra Aetate, but there were seven others, most from the Reform/Calvinist tradition of which the Presbyterians are a part. They specifically mentioned two groups with which the Presbyterians are affiliated, the World Council of Churches and the World Alliance of Reformed Churches.

The statement said that their six years of study and discussion had helped them to "see many things in a new light....The study has helped us to feel the pain of our Jewish neighbors who remember that the Holocaust was carried out in the heart of 'Christian Europe' by persons many of 
whom were baptized Christians. We have come to understand in a new way how our witness to the gospel can be perceived by Jews as an attempt to erode and ultimately destroy their own communities" (p. 3).

The document focused upon seven "theological affirmations":

(1) a reaffirmation that the God who addressed both Christians and Jews is the same - the living and true God;

(2) a new understanding by the church that its own identity is intimately related to the continuing identity of the Jewish people;

(3) a willingness to ponder with Jews the mystery of God's election of both Jews and Christians to be a light to the nations;

(4) an acknowledgement by Christians that Jews are in a covenant relationship with God and the consideration of the implications of this reality for evangelism and witness;

(5) a determination by Christians to put an end to "the teaching of contempt" for the Jews;

(6) a willingness to investigate the continuing significance of the promise of "land" and its associated obligations and to explore the implications for Christian theology;

(7) a readiness to act on the hope which we share with the Jews in God's promise of the peaceable kingdom. (p. 3).

\section{Theological Understanding specifi-} cally repudiated replacement theology in the discussion of point two: "We affirm that the church, elected in Jesus Christ, has been engrafted into the people of God established by the covenant with Abraham, Isaac, and Jacob. Therefore, Christians have not replaced Jews." Furthermore,
"We believe and testify that this theory of supersessionism or replacement is harmful and in need of reconsideration..." (p. 9). On point three, it states, "We affirm that both the church and the Jewish people are elected by God for witness to the world and that the relationship of the church to contemporary Jews is based on that gracious and irrevocable election of both." On point six they "affirm the continuity of God's promise of land along with the obligations of that promise to the people of Israel."

They did add one statement that might not be universally pleasing: "As Reformed Christians, however, we believe that no government at any time can ever be the full expression of God's will. All, including the State of Israel, stand accountable to God. The State of Israel is a geopolitical entity and is not to be validated theologically." Moreover, God's promise of "land" to the Jews cannot be seen "solely in terms of a specific geographical entity on the eastern shore of the Mediterranean...."

On another point, they called into question the doctrine of Christian Zionism, which has been so friendly to the Israeli right. "We disavow those views held by some dispensationalists and some Christian Zionists that see the formation of the State of Israel as a signal of the end of time, which will bring the Last Judgment, a conflagration which only Christians will survive" (pp. 14-15).

Rabbi Bretton-Grantoor dismissed this document out of hand: "True, a white paper on these questions has been circulating around the Presbyterian church since the mid-1980s, but it was never acted upon." This statement ("circulating around") is incorrect and unhelpful.

To understand the significance of this document, one must consider the structure of church teaching authority. In the Pres- 
byterian tradition, there is a hierarchy of theological statements and teachings. At the highest level are the 11 official "Confessions" of the church. Some are shared by other Christians, such as the Apostles Creed and the Nicean Creed. Others peculiar to the Presbyterian or Reform tradition would include the Westminster Confession and the Theological Declaration of Barmen (which renounced Nazism as a heresy and got many of its signatories killed). These are an official Few individual members read these rather complex publications, but as officially recommended documents their impact on seminaries and ministers would be significant.
Rabbi Bretton-Granatoor is a respected person of exceptional stature. He is not an intemperate ideologue or an official in a chauvinist organization. His essay received wide distribution through the Jewish Telegraphic Agency (JTA), a news service used by Jewish newspapers across the country (and available to any individual via email). Jewish lay people (not to mention rabbis part of the "constitution" of the church, the Book of Confessions. ${ }^{36}$ Church officials pledge to use them for guidance.

On the other end, there are a host of materials issued by agencies of the church. Examples would be the monthly magazines and Sunday-school materials. These are official publications coming from denominational headquarters. Zionism Unsettled was issued by an affiliated interest group and was not official in any way.

But let's return to the top of the hierarchy. Just below the "Confessions" are statements and documents adopted or recommended by the General Assembly. Theological Understanding would be one of these. An official teaching document would be of considerable significance. In practice, few individual members read these rather complex publications, but as officially recommended documents their impact on seminaries and ministers would be significant. Like a papal encyclical, their primary impact is to guide pastoral teaching. A pastor who systematically deviated from such a teaching would be rare, and might well be challenged.
Presbyterians have not engaged the issue of anti-Semitism, and in fact still embrace it, would cause even a thoughtful Jewish reader to pull back from any respectful consideration of what might motivate the supporters of the divestiture overtures. It would certainly contribute to a gap between Presbyterians and Jews. Whether the distortion was from poor analysis or intent, the allegations went beyond just being inaccurate. They were harmful.

\section{Jewish Voice for Peace}

An organization that stood out for contributing a respectful tone to this debate was Jewish Voice for Peace (JVP). Its written statements and the comments and demeanor of its representatives were consistently gentle and focused. They supported the Presbyterian vote, but they did more. They made the dialogue civil.

JVP is part of a cluster of dissenting Jewish groups that are openly critical of the occupation and the settlement structure. Others in that cluster would be J Street and Americans for Peace Now. Some of these, including JVP, have been excluded 
Middle East Policy, Vol. XXII, No. 1, Spring 2015

from various Jewish-community umbrella groups and events. They are not a large group although they claim to be in contact with 100,000 individuals. Their mission statement says they are "inspired by Jewish Tradition to work together for peace, social justice, equality, and human rights." ${ }^{37}$ The Anti-Defamation League (ADL) has a different perspective. It has called them "a leader in the American anti-Israel movement," a group so vehement that "they oppose Israel's very existence." 38

Prior to the General Assembly, members of JVP's Rabbinical Council met with the Presbyterian leadership to discuss the issues before the body. In an Open Letter ${ }^{39}$ they discussed that meeting with their "friends." They had asked, "What does your conscience tell you to do in response to the military occupation of the West Bank? Overwhelmingly, you replied, 'My conscience tells me to vote to divest the church's funds from American companies that support the occupation; we do not invest in tools of war." But then you added a concern: "What will the Jewish people in my life say: the rabbi I know, my Jewish cousins, my Jewish neighbors. Many of these Jews have emailed me or called me, asking me not to divest. I value my relationship with Jewish people and I do not want to undermine those relationships." You told us, "We are sensitive to the feelings of those Jews who oppose divestment. But we cannot choose to ignore the daily suffering of Palestinians and the shockingly routine loss of Palestinian life living under Occupation." Here is our advice to you:

Listen to your inner voice of conscience. We do not believe that the risk of hurting the feelings of some — or even many — Jews should take precedence over responding to the constant humiliation and violent attacks on Palestinians living under Occupation....Jews will continue to debate with each other how to best support peace and justice in IsraelPalestine. Let us allow the Presbyterian General Assembly the same freedom - the freedom to choose how to align the church's investments with your ethical commitments.

JVP believes that Israel is not only at risk from its own actions and policies, but that its policies in the Palestinian territories are compromising the great Jewish teachings of justice. Even when attacked, JVP did not respond in kind. It was as if its members were determined not to break that last remaining tie to others within the Jewish community, regardless of what happened. There is an old Jewish teaching, "Do not separate yourself from the community." They were denounced for doing exactly that, of breaking ranks with the positions of their community leadership. They saw their actions in a very different way, and they approached intra-ethnic disputes in a very different way.

The reaction of the Jewish leadership to Jewish Voice for Peace was very hostile. Rabbi Eric H. Yoffe, former president of the Union for Reform Judaism, a centrist group with some progressive leanings, expressed views that were widely shared. ${ }^{40}$ After noting that he was "not too happy" with the "profoundly unfortunate and mistaken decision" of the church, he also found something "unsettling and dishonest about how all of this played out." He was concerned that Jews were providing cover for the decision:

My view is that the church desperately wanted Jewish backing as cover for their pro-divestment position and Jew- 
ish Voice for Peace became the instrument for providing that backing - or, perhaps, a means for church leaders to delude themselves into thinking that Jewish backing really exists. Either way, none of this would have worked without the collusion of Jewish Voice for Peace, which has a tradition of cloaking extremist principles in ambiguous language.

He continued: they represent a "radical anti-Israel position" which, "while it does not call for Israel's destruction, does not affirm her right to exist either." Their participation, according to Yoffe, allowed the church to pass a divestment

\section{For Jews, it was "powerful and painful} to hear the word of conscience spoken in our direction. But we would be wise to listen, or at least to show respect to the testimony being voiced by this selective divestment overture." conscientious investment to oppose apartheid in South Africa, to call for mine safety in the U.S., to oppose certain kinds of weapon manufacture and trade and to protest unjust regimes in Burma and Sudan. This year, in addition to considering divestment from the three corporations involved in the occupation of Palestine, the PCUSA will also be hearing overtures to divest from drone manufacturers and fossil fuel developers....Our [JVP's] greatest hope is that the Jewish people would hear selective divestment from resolution "without seeming too extreme."

But JVP had its own perspective on what the vote meant. Rabbi Margaret Holub of its Rabbinical Council outlined the issues: "When religious communities invest their funds, their choices bear witness to the world as they believe it should be. Choosing to remove your money from entities that offend your vision of a just world is not just an act of conscience; it is a speaking of the world." For Jews, it was "powerful and painful to hear the word of conscience spoken in our direction. But we would be wise to listen, or at least to show respect to the testimony being voiced by this selective divestment overture." The Presbyterian Church has

[L]ong used the placement of their material resources to speak their vision of justice. Over the past 30 years they have spoken the language of
American religious landscape, calling us to task for a cruel policy that brings pain to their own brothers and sisters in the Palestinian Christian community and to all who live under Israeli occupation. Far from being hate speech, it is the speech of conscience. ${ }^{41}$

\section{PUBLIC HEARINGS}

On the first day of the General Assembly, three hours were devoted to statements from individuals on the Middle East overtures. Each person was given 90 seconds, with pro and con opinions alternating. While 90 seconds may seem short, speakers were able to say quite a bit in that time. Opponents often mentioned the "pain" the vote would have for Jewish friends. One supporter mentioned talking to a white South African who told how grateful he was for the divestment movement against the apartheid regime in the 1980s. It had 
helped the regime realize that it needed to change. Someone from JVP advised the commissioners to stay true to their values. We, as Jews, she said, disagree with each other; we will continue our discussions within our community without your input, and you should make your decisions without concern for the fact that some Jews may disagree with you. One of my Palestinian-American students (whose photo was chosen for the front page of The New York Times) spoke on behalf of divestment. Here is how she described her 90 seconds of fame:

The best part of speaking for divestment at the presby GA today was definitely that the woman who spoke before me said a Palestinian Christian told her that "Arabs want to push Jews into the sea." So I got to stand up right after her and tell the room "I'm a Palestinian Christian, and I can tell you we don't want to push anyone into the sea. We're just tired of being denied the right to swim in the same water." I'd like to thank that woman for setting me up to use that awesome quote.

\section{THE FINAL TEXT}

After hearings, deliberations, votes and reconsiderations, the General Assembly finally received a text upon which it would vote. The reader will note that there is no call for a boycott, no call for divestment and no call for sanctions. These would be imposed by a government, not a church. ${ }^{42}$

The PC (USA) has a long-standing commitment to peace in Israel and Palestine. We recognize the complexity of the issues, the decades-long struggle, the pain suffered and inflicted by policies and practices of both the Israeli government and Palestinian entities. We further acknowledge and confess our own complicity in both the historic and current suffering of Israelis and Palestinians. Yearning for justice and reconciliation, the 221 st General Assembly (2014) recommends the following:

\section{Reaffirm Israel's right to exist as a sovereign nation within secure and internationally recognized borders in accordance with the United Nations resolutions.}

2. Declare its commitment to a negotiated two-state solution (two states for two peoples) in which a secure and universally recognized State of Israel lives alongside a free, viable, and secure state for the Palestinian people.

\section{Instruct the Presbyterian Founda-} tion and the Board of Pensions of the PC (USA), to divest from Caterpillar, Inc., Hewlett-Packard, and Motorola Solutions, in accord with our church's decades-long socially responsible investment (SRI) history, and not to reinvest in these companies until the Mission Responsibility Through Investment Committee of the PC (USA) is fully satisfied that product sales and services by these companies are no longer in conflict with our church investment policy. This action on divestment is not to be construed or represented by any organization of the PC (USA) as divestment from the State of Israel, or an alignment with or endorsement of the global BDS (Boycott, Divestment and Sanctions) movement.
4. Reaffirm PC (USA)'s commitment to interfaith dialog and partnerships with the American Jewish, Muslim friends and Palestinian Christians and call for all presbyteries and congrega- 
tions within the PC (USA) to include interfaith dialogue and relationshipbuilding as part of their own engagement in working for a just peace.

5. Call for all foreign aid given by the U.S. government - including aid to Israel and the Palestinian Authority - to be comprehensively and transparently accounted to the American people and held to the same standards of compliance with all applicable laws.

6. Call for church advocacy for foreign-aid accountability to be directed toward its universal adherence rather than targeted for selective application to some recipients and not others.

7. Encourage Presbyterians to travel to the Holy Land, and give broad support to the Christian, Jewish, and Muslim communities throughout the Middle East.

8. Affirm the importance of economic measures and cooperation between Israelis and Palestinians that support and advance a negotiated two-state solution.

9. Urge all church institutions to give careful consideration to possible investments in Israel-Palestine that advance peace and improve the lives of Palestinians and Israelis.

\section{THE AFTERMATH}

Several questions remain as we try to assess what happened in Detroit. One is why Presbyterians voted as they did. While one should be cautious in generalizing about how 613 individuals made their decisions, some informed hypotheses might help. Those supporting the overtures appeared to be driven by an awareness of the Palestinian situation and a determination to adhere to the longstanding commitment of the church to keep its investments free of entanglements with war or injustice. Those on the other side seemed more likely to accept the Israeli version of events and were less driven by Middle East conflict than by engagement with Jewish neighbors and friends.

After the General Assembly ended, the divisions remained as before. Several Jewish groups issued strong statements denouncing what had happened while the JVP thanked the Presbyterians for their courage and integrity. On the Presbyterian side, the opponents of the decisions, led by Reverend Leighton, put a full-page advertisement in The New York Times ("We Can Do Better Than Divestment") criticizing the vote and calling for a new approach, while former moderator Ufford-Chase issued a statement that this was only the first step in bringing peace to the region. ${ }^{43}$

As historians look back, will they see this as a turning point of some sort? That certainly seemed the case in 2004, when the Presbyterians first addressed these issues. In 2014, the situation was very different. In 2004, the Presbyterian vote was the first of its kind from a major denomination. It was quickly followed by votes, or at least debates, in several other denominations. A decade later, what the Presbyterians did was not so dramatic. Perhaps the ice was broken earlier so that this was not as significant as it seemed on the floor (or on the front page of The New York Times).

\section{Statements from Denominational Leaders}

In the immediate aftermath of the vote, there was a definite effort at damage control. From the stage, the new moderator said, "In no way is this a reflection of our lack of love for our Jewish sisters and 
Middle East Policy, Vol. XXII, No. 1, Spring 2015

brothers." ${ }^{44}$ There was also the announcement that the church would no longer sell Zionism Unsettled through its sales outlet. ${ }^{45}$

If this seemed like a stepping-back, an Open Letter from the top three denominational leaders to our "American Jewish Interfaith Partners" was quite different. ${ }^{46}$ A letter such as this always involves a delicate dance between conciliatory words and the avoidance of any hint that there is something for which the church should be apologetic. Presbyterians are of the Calvinist tradition and believe that all individuals are tainted by sin. Every week in their services they "confess" these sins. They assume that if there is a conflict, both sides have played a role and should ask for forgiveness. To outsiders, such a confession can sound as if the denomination is admitting it made a mistake. That is not the purpose of a confession.

The letter was very blunt about the issue, which was the occupation of Palestinian lands. It said about the three companies: "The assembly concluded that further engagement would not bring an end to their pursuits that further the Israeli occupation in Palestine." On the interfaith issue, "The close nature of the vote revealed how deeply Presbyterians care about both Jewish and Palestinian neighbors...." The vote was but one example of "our commitment to ethical investing." It specifically "was not in support of the global BDS movement." In a statement that must have stunned many Jews, the letter said, "We are pressed and challenged to follow our faith values and commitments in all times and in all areas of our lives. The occupation must end."

They then attached the actual resolution as adopted. This was clearly an effort to neutralize the false versions of their actions that were widely disseminated.

\section{Some Jewish Reactions}

Several Jewish organizations positioned on the right of the community spectrum expressed strong opposition to what had happened. Some used intemperate language. Rabbi Abraham Cooper of the Simon Wiesenthal Center said he was "shocked beyond words" at the vote. The Presbyterian Church had exhibited "an ugly spectacle of righteous hypocrisy" when it choose to "flex its moral muscles by aiding and abetting those pledged to do away with the Jewish state." The Presbyterians "tolerate overt anti-Semitism" and "have reverted to the pre-Holocaust stance of an adversarial relationship with the Jewish community." 47 The American Jewish Committee said that the vote was "driven by hatred of Israel." 48 Rabbi Noam Marans, AJC director of Interreligious and Intergroup Relations, said the Presbyterians were "demonizing" Israel and engaging in "propagandist indoctrination." Their vote "is celebrated by those who believe they are one step closer to a Jew-free Middle East." ${ }^{49}$ The ADL said that the church's decision to divest "from companies doing business with Israel" came "in the context of years of hostility." Church leaders "have fomented an atmosphere of open hostility to Israel" and "permitted the presentation of a grossly distorted image of the views of the Jewish community." 50 A surprising statement came from the prime minister of Israel, who decided to inject himself into this ecclesiastical issue. Benjamin Netanyahu first delivered a statement to 300 Jewish journalists, urging them to "defeat a lie...with truth, with facts, with courage." Then, on Face the Nation, he called the vote "disgraceful" and said "it should trouble all people of conscience...."

In the other direction, Jewish Voice for Peace issued a statement saying it 
would like to congratulate and celebrate the vote. "The Church has a long history of ethical investment choices, and it is a strong signal of its commitment to universal human rights that it chooses to divest. This is a turning point. The Presbyterians' decision is a major development in the longstanding work to bring the U.S. into alignment with the rest of the world....As this movement for justice grows, we call on Jewish institutions who claim to oppose the occupation to drop their spurious criticisms of divestment and instead join us in taking concrete action to change policy. Divestment is inclusive, nonviolent, and in line with Jewish values." ${ }^{2}$

\section{ASSESSMENT}

To the Presbyterians who supported these overtures, they were affirming their faith and values and clarifying their theology. But to pro-Israeli activists, Jewish or Presbyterian, it was something very different. It was a perfect storm of multifront attacks. The overtures not only separated a major denomination rooted in a moral tradition from Israel economically and morally but they attacked Israel's Christian Zionist allies and even questioned the use of the word "Israel" in liturgy. And in spite of back-peddling, they had generated a study guide that condemned Israel as an apartheid state and associated it with some of the most venomous regimes in history, including the one that had dedicated itself to the total destruction of the Jewish people. All of this came in the wake of a previous call for Congress to cut off aid to Israel and investigate it for war crimes.

In South Africa, the divestiture and "apartheid is heresy" movements worked in part because whites and blacks shared a religion and a history. Archbishop Tutu could speak to Afrikaners in a religious vocabulary that facilitated communication. Jews do not share common religious vocabulary or memories with Presbyterians or Palestinians. When a Presbyterian official says that we want to express our love for our Jewish sisters and brothers, it sounds insincere and manipulative. When a prominent Jewish leader calls the Presbyterian Church anti-Semitic, it sounds venomous and excessive. JVP hoped that this vote might generate a reassessment within the Jewish community regarding their support for Israeli policies. A far more likely outcome is the one predicted by some opponents of the overtures: that even debating them would empower hardline thinking. Sad to say, in spite of the best efforts of Presbyterian leaders and Jewish moderates, it already has.

\footnotetext{
${ }^{1}$ Regarding 2012, "Frequently Asked Questions," pcusa.org/resource/faq-middle-east-issues.

${ }^{2}$ See Ronald R. Stockton, "The Presbyterian Divestiture Vote and the Jewish Response," Middle East Policy 12, no. 4 (Winter, 2005): 98-117; and Ronald R. Stockton, "Presbyterians, Jews and Divestment: The Church Steps Back," Middle East Policy 13, no. 4 (Winter, 2006): 102-124.

${ }^{3}$ For details, see pcusa.org/news/2012/10/5. For the Jewish response, see Laurie Goodstein, "Church Appeal on Israel Angers Jewish Groups," New York Times, October 20, 2012; and Nathan Guttman, "Jewish Groups Resume Dialogue with Churches after Israel Aid Schism," Forward, April 18, 2014.

4 “Presbyterian Panel," August 2009, pcusa.org/resource/Presbyterian-panel-survey-august-2009.

5 “A Portrait of Jewish Americans," Pew Research Religion \& Public Life Project, October 1, 2013, PewForum.org/2013/10/01/Jewish-American-beliefs-attitudes-culture-survey.
} 
Middle East Policy, Vol. XXII, No. 1, Spring 2015

${ }^{6}$ Presbyterian News Service, "Presbyterian Mission Agency Board Sends MRTI Recommendations to Gen-
eral Assembly," February 7, 2014.
${ }^{7}$ www.bdsmovement.net, accessed December 12, 2014.
${ }^{8}$ Laurie Goodstein, "Methodist Church Pension Board Links Divestment to Firm's Role in Israeli Prisons,"
New York Times, June 15, 2014.
${ }^{9}$ Arthur Herzberg, The Zionist Idea. A Historical Analysis and Reader (Atheneum, 1977), contains an edited
version of Herzl's Der Judenstaat (1896) as well as other Zionist writings.
${ }^{10}$ Zionism and the Quest for Justice in the Holy Land (Wipf and Stock, 2014), Donald E. Wagner and Walter
T. Davis, eds., with an introduction by Walter Bruggemann.
${ }^{11}$ Zionism Unsettled: A Congregational Study Guide (IPMN of the Presbyterian Church, 2014).
${ }^{12}$ Apartheid Is a Heresy, John W. DeGruchy and Charles Villa-Vincencio, eds. (Cape Town: David Philip,
1983 ; quotes from 154-155, “A Message to the People of South Africa”).
${ }^{13}$ Ronald R. Stockton, "Christian Zionism: Prophecy and Public Opinion, Middle East Journal (Spring 1987):
$234-253$.
${ }^{14}$ "A Portrait of Jewish Americans," Pew Research Religion \& Public Life Project, October 1, 2013, PewFo-
rum.org/2013/10/01/Jewish-American-beliefs-attitudes-culture-survey.
${ }^{15}$ "Religion and Politics: Contention and Consensus," Pew Research Center for the People \& the Press, July 24, 2003.

16 "Resolution on Confronting Christian Zionism," $216^{\text {th }}$ General Assembly, 2004.

${ }^{17}$ Presbyterianmission.org/ministries/global/Israel-and-palestine-general-assembly-statements.

${ }^{18}$ Glory to God (Westminster/John Knox Press, 2013).

${ }^{19}$ Works that discuss how historic archetypes influence current thinking include John Keen, Faces of the Enemy: Reflections of the Hostile Imagination (Harper Row, 1991); Ronald R. Stockton, "Ethnic Archetypes and the Arab Image," in Ernest McCarus, ed., The Development of Arab-American Identity (University of Michigan Press, 1994), 119-154; J. Michael Aronson, Troubled Waters: Origins of the 1881 Anti-Jewish Pogroms in Russia (University of Pittsburg Press, 1990); and John Dower, War without Mercy. Race and Power in the Pacific War (Pantheon, 1987). A standard work on prejudicial thinking is Gordon Allport, The Nature of Prejudice (Doubleday and Company, 1958), especially pp. 13-14.

${ }^{20}$ Johnvest.com/2014/06/13.

${ }^{21}$ Duke claimed credit for the term supremacism, which was used in the booklet. Posted February 11, 2014, on his website, davidduke.com.

${ }^{22}$ Ironically, the Afrikaners of apartheid South Africa considered themselves inheritors of the Hebraic covenant. W. A. DeKlerk, The Puritans in Africa. A Story of Afrikanerdom (Penguin Books, 1976).

23 "We Refuse to be Enemies," PresbyPeaceFellowship.org, June 14, 2014.

${ }^{24}$ Posted on www.israelpalestinemissionnetwork.org, June 10, 2014.

25 "Israel, the PCUSA, and 'Divestment,"” Beloved Spear.org, June 17, 2014.

26 "An Open Letter to the Presbyterian Church," February 6, 2014, icjs.org.

${ }^{27}$ Two documents provide an interesting juxtaposition of the criticisms and defenses of this study guide. The Ecumenical and Interreligious Work Group of the Chicago Presbytery issued a critique ("Statement of EIWG on Zionism Unsettled," Pfmet/org/press/releases/137/EIWG-statement-on-zionism-unsettled, undated), while the Israel/Palestine Mission Network issued a strong response. ("IPMN Responds to Chicago Group's mischaracterization of Zionism Unsettled.” Israelpalestinemissionnetwork.org/ main/advocacy/statements/263). ${ }^{28}$ JTA 6-6-14. "As Presbyterians Again Weigh Divestment, Jewish Groups Lobby, Warn and Worry."

${ }^{29}$ Noam E. Marans, "Presbyterians, BDS and Israel - Here We Go Again," May 30, 2014, Jewish Telegraphic Agency op-ed, JTA.org/2014/05/30/news-opinion.

${ }^{30} \mathrm{Spme}$.org/boycotts-divestments-sanctions-bds.

${ }^{31}$ Posted on www.inpursuitofpeace.org.

${ }^{32}$ Rabbi Rick Jacobs, June 19, 2014, Blogs.rj.org/blog/2014/06/19. He told the commissioners that if they voted down the overtures in dispute, he would arrange a meeting between their leaders and Prime Minister Netanyahu. The New York Times said the offer "appears to have backfired, with some saying afterward that it felt both manipulative and ineffectual, given what they perceive as Mr. Netanyahu's approval of more settlements in disputed areas and lack of enthusiasm for peace negotiations" (Laurie Goldstein, "Presbyterians Vote to Divest Holdings to Pressure Israel," New York Times, June 20, 2014). See also "URG's Jacobs Invites 
Presbyterian Leaders to Join Him in Netanyahu Meeting," JTA, June 19, 2014. See also Jerry L. Van Marter, General Assembly News, "Divestment Decision Immediately Becomes Target In and Outside Cobo Center," Pcusa.org/news/2014/6/21.

${ }^{33}$ Rabbi Gary M. Bretton-Granatoor, vice president of the World Union for Progressive Judaism, in "The Presbyterians' Judaism Problem," Jewish Telegraphic Agency, June 27, 2014.

${ }^{34}$ St. Augustine, perhaps the greatest of all Catholic theologians, said God protected the Jews from final destruction even though they were "blinded" so as to show the Church "in her enemies the Jews the grace of His compassion." See The City of God, Marcus Dods, trans.; introduction by Thomas Merton (Modern Library, undated), particularly Books 18, 28, 29, 46, 53.

35 "A Theological Understanding of the Relationship between Christians and Jews; A Paper Commended to the Church for Study and Reflection by the $199^{\text {th }}$ General Assembly" (Presbyterian Church [USA], 1987), available through the Office of General Assembly, PCUSA.org.

${ }^{36}$ Presbyterian Church (U.S.A.), Book of Confessions, creeds.net/reformed/Book of Confessions.

${ }^{37}$ JewishVoiceForPeace.org, accessed December 5, 2014.

${ }^{38}$ www.adl.org/anti-Israel-activity/c/backgrounder-Jewishvoice.html, accessed December 5, 2014.

${ }^{39}$ Rabbinical Council of Jewish Voice for Peace, “An Open Letter to Our Presbyterian Friends," June 19, 2014, Huffingtonpost.com/cantor-michael-davis.

${ }^{40}$ Rabbi Eric H. Joffe, "How a Radical Anti-Israel Jewish Group Colluded with the U.S. Presbyterian Church," Haaretz, June 23, 2014.

${ }^{41}$ Rabbi Margaret Holub, co-chair of the Rabbinical Council of Jewish Voice for Peace. "I'm a Rabbi and I support Presbyterians' Partial Israel Divestment.” Forward.com, June 16, 2014.

${ }^{42}$ One overture that was approved called upon the Advisory Committee on Social Witness Policy to produce a history of General Assembly policies endorsing a two-state solution. Critics said this was a call for a onestate solution which would mean the end of Israel. In fact the committee was asked to recommend whether the church should continue this policy (which appears to have failed) or should shift to a "neutral stance that seeks not to determine for Israelis and Palestinians what the right 'solution' should be." For a discussion of all relevant actions at the General Assembly, see "Frequently Asked Questions: Divestment," at Pcusa.org/ resource/faq-middle-east-issues.

${ }^{43}$ Leighton's advertisement in The New York Times was on November, 20, 2014.

44 "By Slim Margin Assembly Approves Divestment from Three Companies Doing Business in Israel/Palestine," June 20, 2014, pcusa.org/news/2014/6/20.

45 "Effective immediately, the publication Zionism Unsettled, will no longer be sold on the Presbyterian Church (U.S.A.) website. Last week in Detroit, the $221^{\text {st }}$ General Assembly passed a resolution declaring that the booklet Zionism Unsettled 'does not represent the views of the Presbyterian Church (U.S.A.).' The IsraelPalestine Mission Network, which produced the booklet, may continue to sell and distribute it through other channels," June 27, 2014. See "Frequently Asked Questions" at pcusa.org/resource/faq-middle-east-issues. Presbyterian Mission Agency, June 27, 2014, pcusa.org/news/2014.

${ }^{46}$ Moderator Heath Rada, Stated Clerk Gradye Parsons and Linda Bryant Valentine, head of the Presbyterian Mission Agency, June 26, 2014, oga.pcusa.org/statements/news.

${ }^{47}$ Simon Wiesenthal website, June 20, 2014.

48 "U.S. Presbyterians Vote to Divest from Companies Used by Israel in Occupied Territories," Haaretz, June 23, 2014.

${ }^{49}$ American Jewish Committee, "Presbyterian Divestment A Breach with Jews, Undermines Israeli-Palestinian Peace," June 23, 2014, ajc.org.

${ }^{50}$ The Anti-Defamation League, “ADL Disappointed by Presbyterian Church's Decision to Support Divestment from Israel," press release, adl.org/press-center/press-releases), June 20, 2014.

${ }^{51}$ CBNNews.com, June 27, 2014, and "Netanyahu Blasts Presbyterian Divestment as 'Disgraceful,"” Haaretz, June 22, 2014.

${ }^{52}$ Cecile Suransky, Jewishvoiceforpeace.org, June 20, 2014. 